\title{
PHASE ANALYSIS OF THE SLAG AFTER SUBMERGED-ARC WELDING
}

\author{
ANALIZA FAZ V ŽLINDRI PRI OBLOČNEM VARJENJU POD \\ PRAŠKOM
}

\author{
Marica Prijanovič Tonkovič ${ }^{1}$, Jakob Lamut ${ }^{2}$ \\ ${ }^{1}$ High Mechanical Engineering School, Šegova 112, 8000 Novo Mesto, Slovenia \\ ${ }^{2}$ University of Ljubljana, Faculty of Natural Sciences and Engineering, Aškerčeva cesta 12, 1000 Ljubljana, Slovenia \\ marica.prijanovic-tonkovic@guest.arnes.si \\ Prejem rokopisa - received: 2015-01-16; sprejem za objavo - accepted for publication: 2015-03-04
}

doi:10.17222/mit.2015.014

\begin{abstract}
The quality of a weld depends, to a large extent, on the filler material and type of welding. Welds and surfacing welds were produced with submerged-arc welding. The welding current was varied. The flux with a fineness of $0.2-1.8 \mathrm{~mm}$ was used. During the welding process, the welding flux melted and the liquid slag was formed. After the input of heat was stopped, the solidification of the slag began and different mineral phases started to precipitate. We found out that besides the basic constituents listed by the manufacturer of the welding flux, the alloying elements and deoxidizers from the flux and from the melt are also present in the slag. Based on these results, it can be concluded that in the case of reusing the welding slag for the production of welding flux, it is important to consider the composition of the welding slag.

Keywords: submerged-arc welding, welding flux, welding slag

Na kakovost zvara ima velik vpliv dodajni material ter postopek varjenja. Zvari in navari so bili izdelani po postopku varjenja pod praškom. Tok varjenja se je spreminjal. Uporabljen je bil varilni prašek, zrnatosti od 0,2 do $1,8 \mathrm{~mm}$. Med varjenjem se je varilni prašek stalil in nastala je tekoča žlindra. Po končanem dovajanju toplote se je začelo strjevanje žlindre in v žlindri so se izločale različne mineralne faze. Ugotovili smo, da na mineralno sestavo žlindre vplivajo poleg osnovnih sestavin, ki jih navaja proizvajalec varilnega praška, tudi legirni elementi in dezoksidanti iz praška in iz taline. Na osnovi rezultatov preiskav sklepamo, da je pri ponovni uporabi varilne žlindre za izdelavo varilnega praška pomembno, da se upošteva tudi sestavo varilne žlindre.

Ključne besede: varjenje pod praškom, varilni prašek, žlindra po varjenju
\end{abstract}

\section{INTRODUCTION}

The quality of welds and surfacing welds depends on the chemical composition of the filler and base material as well as on the method of welding, determining the heat input which influences the development in the heataffected zone and in the melt during the welding process. The slag, formed during the process of flux melting, plays an important role. ${ }^{1}$ The slag accompanies the metal during the wire fusion and it covers the melt and protects it until it solidifies. The welding slag can be used again for the flux preparation. ${ }^{2}$

The important welding parameters are the welding current, the voltage and the speed of welding. ${ }^{3}$ If the current is too high, degassing in the weld is weak and cracks occur. Raising the current increases the depth of remelting the base material. ${ }^{4}$ Surfacing with a low welding current $(450 \mathrm{~A})$ is recommended in the case of using the alloyed agglomerated fluxes. ${ }^{5}$

Slag is formed during the melting of the fluxes that lead to the ionisation of the arc atmospere and deoxidation of the melt, enable the passage of the alloying elements into the melting bath and prevent oxidation of carbon, manganese and silicon. Many types of welding fluxes are in use and they differ by the main mineral content and the presence of metal additives. ${ }^{6-10}$ Recycled SAW slag can be used as a welding flux. ${ }^{8}$

For the investigations, the agglomerated flux labelled as FB 12.2, ${ }^{11}$ suitable for reaching a high toughness in multipass welds, was used. The width of the heataffected zone (HAZ) of steel OCR12 VM ${ }^{12,13}$ welded with the submerged-arc welding method depends on the welding current. ${ }^{14}$ Figure 1a shows the microstructure at the HAZ/weld border at a current of $470 \mathrm{~A}$, and Figure 1b shows the effect of a current of $610 \mathrm{~A}$. The mineral composition of the slag, formed during the welding process, was determined.

\section{EXPERIMENTS}

Four different welds were produced, two welds and two surfacing welds. Figure 2a presents a steel sample, used for welding. Figure $\mathbf{2 b}$ presents a surfacing weld. The welding was carried out on a device for submergedarc welding made by Iskra. The chemical compositions of the welding pieces (steel OCR12 VM) and the filler material are presented in Table $\mathbf{1}$.

The applied basic welding flux ${ }^{11}$ is used for automatic welding and surfacing of construction steels. 
Table 1: Chemical composition of base steel and filler material

Tabela 1: Kemijska sestava osnovnega jekla in dodajnega materiala

\begin{tabular}{|c|c|c|c|c|c|c|c|c|}
\hline \multirow{2}{*}{ Type of material SIST EN 10027-2 } & \multicolumn{8}{|c|}{ Chemical composition $(w / \%)$} \\
\hline & $\mathrm{C}$ & $\mathrm{Si}$ & Mn & $\mathrm{P}$ & $\mathrm{S}$ & $\mathrm{Cr}$ & Mo & V \\
\hline Welding piece: OCR12 VM (1.2379) & 1.50 & 0.4 & 0.4 & 0.03 & 0.03 & 11.5 & 0.8 & 0.85 \\
\hline Filler material & 0.08 & 0.35 & 1.4 & / & 0.03 & 5.0 & 0.85 & l \\
\hline
\end{tabular}

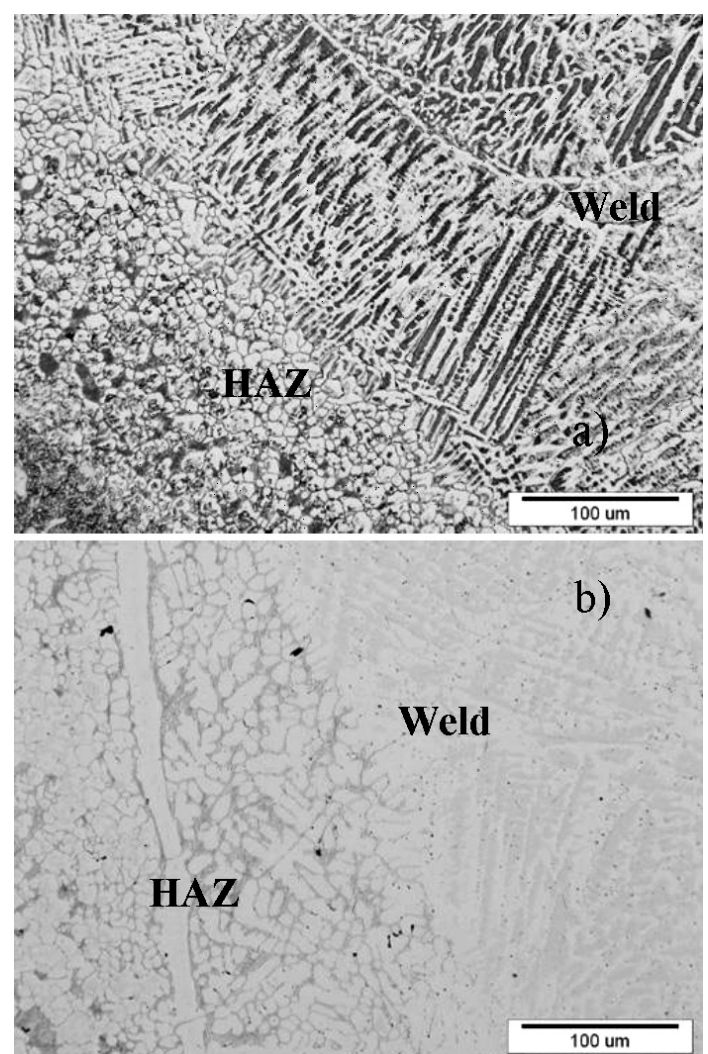

Figure 1: Microstructure of the weld on the HAZ/weld border with a current of: a) $470 \mathrm{~A}$ and b) $610 \mathrm{~A}$

Slika 1: Mikrostruktura zvara na meji CTV/zvar pri toku varjenja: a) $470 \mathrm{~A}$ in b) $610 \mathrm{~A}$

The first joining of the welding pieces was performed with the MAG procedure. Table 2 shows the welding parameters. The current and the voltage were varied during the welding process. The time of welding and the mass of the used welding flux were measured.

Table 2: Welding parameters

Tabela 2: Parametri varjenja

\begin{tabular}{|c|c|c|c|}
\hline Specimen & $\begin{array}{c}\text { Wire } \\
\text { diameter } \\
(\mathrm{mm})\end{array}$ & $\begin{array}{c}\text { Voltage } \\
(\mathrm{V})\end{array}$ & $\begin{array}{c}\text { Current } \\
(\mathrm{A})\end{array}$ \\
\hline Specimen 1 - weld & 3.2 & 28 & 470 \\
\hline Specimen 2 - weld & 3.2 & 27 & 610 \\
\hline $\begin{array}{c}\text { Specimen 3 - } \\
\text { surfacing weld }\end{array}$ & 3.2 & 29 & 450 \\
\hline $\begin{array}{c}\text { Specimen 4 - } \\
\text { surfacing weld }\end{array}$ & 3.2 & 28 & 628 \\
\hline
\end{tabular}

The samples of the flux and slags were examinated with metallography, scanning electron microscopy
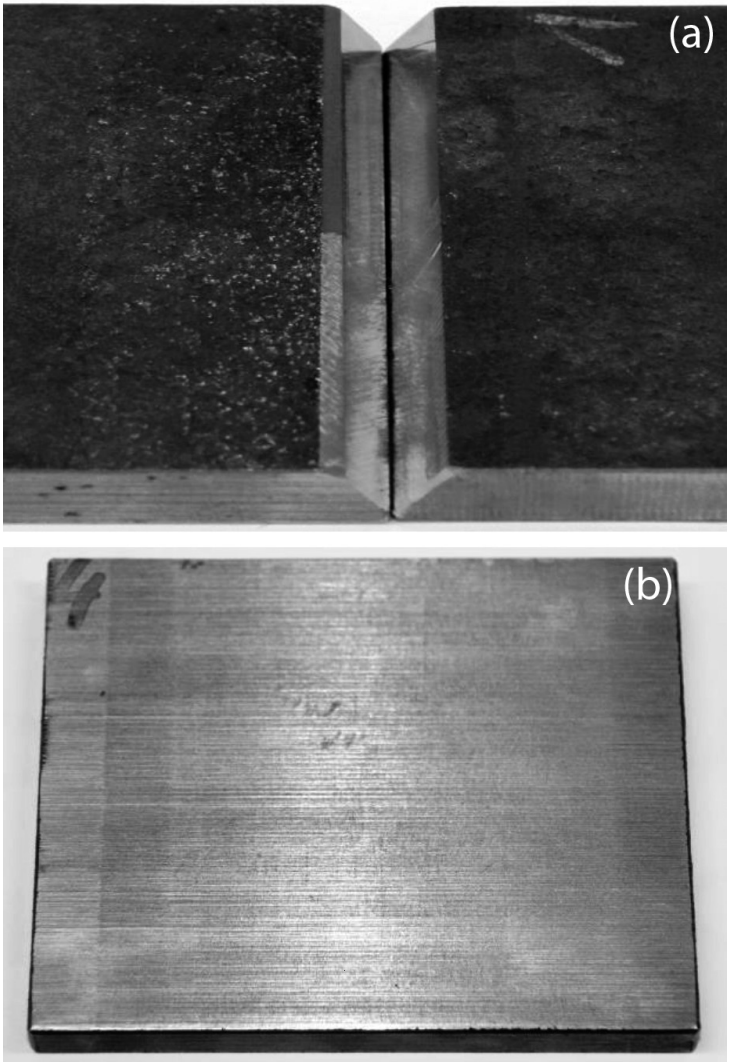

Figure 2: Macro-shot of the welding piece for: a) weld and b) surfacing weld

Slika 2: Makroposnetek varjenca za: a) zvar in b) navar

(SEM) of type JEOL JSM 5610 and analysed with electron dispersive spectroscopy (EDS) of type JEOL JSM 5610 and X-ray diffraction (XRD) of type PANalitical X'pert PRO.

\section{WELDING-FLUX COMPOSITION}

The agglomerated commercial basic welding flux of type FB 12.2 was used for the welding. The chemical composition of the welding flux (Table 3) and the basicity of the flux according to the Boniszewski index of 1.70 were taken from the catalogue. ${ }^{11}$

For the microscopic investigation of the welding flux and welding slag, metallographic samples were prepared. After grinding and polishing, the samples were ready for the metallographic analysis. Figure 3 shows a SEM image of a welding flux composed of non-metallic and metallic materials. 


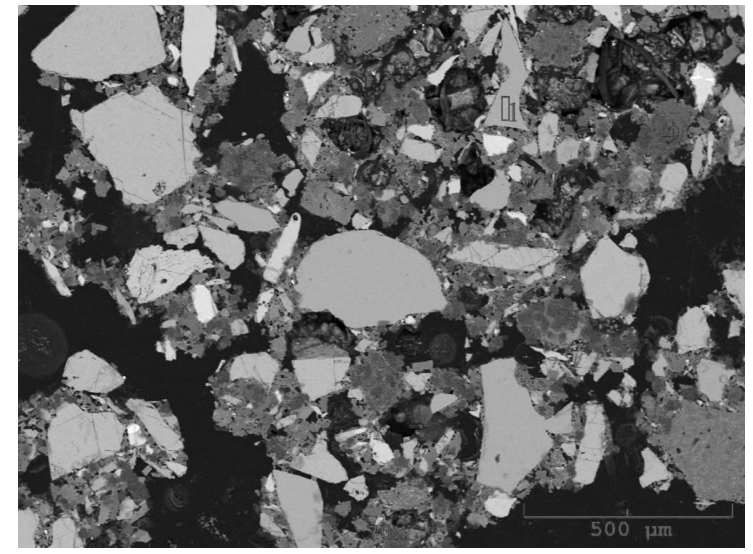

Figure 3: Microstructure of SAW flux

Slika 3: Mikrostruktura EPP praška

Table 3: Chemical composition of welding flux ${ }^{11}$

Tabela 3: Kemijska sestava varilnega praška ${ }^{11}$

\begin{tabular}{|c|c|c|c|c|}
\hline \multirow{2}{*}{$\begin{array}{l}\text { Welding } \\
\text { flux }\end{array}$} & \multicolumn{4}{|c|}{ Chemical composition $(w / \%)$} \\
\hline & $\begin{array}{c}\mathrm{SiO}_{2}+ \\
\mathrm{TiO}_{2}\end{array}$ & $\begin{array}{c}\mathrm{CaO}+ \\
\mathrm{MgO}\end{array}$ & $\begin{array}{c}\mathrm{Al}_{2} \mathrm{O}_{3}+ \\
\mathrm{MnO}\end{array}$ & $\mathrm{CaF}_{2}$ \\
\hline FB 12.2 & 20 & 30 & 25 & 20 \\
\hline
\end{tabular}

The distribution of the elements in the welding flux found with EDS is presented in Figure 4. The area where, on the EDS chart, aluminium overlaps with titanium aluminium oxide, which contains mass fractions of $1.5 \%$ of titanium oxide, is presented.

The region where only calcium can be found indicates the presence of calcium fluorite $\mathrm{CaF}_{2}$. Calcium overlapping with silicon is typical for calcium silicon $(\mathrm{CaSi})$ and wollastonite $\left(\mathrm{CaO} \cdot \mathrm{SiO}_{2}\right)$. As expected, three elements - aluminium, silicon and potassium - overlap with the presence of alumosilicate containing potassium.
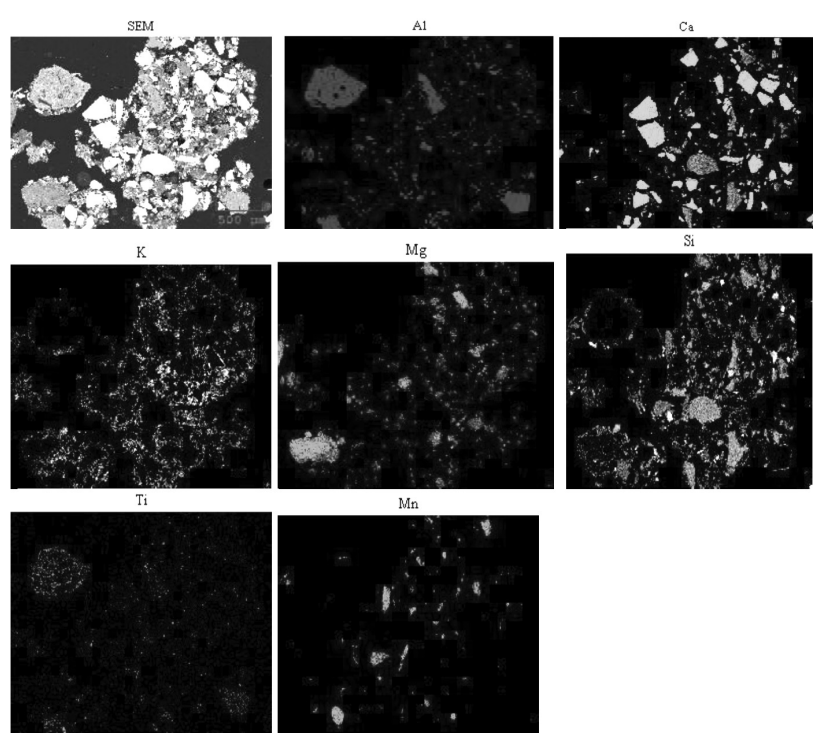

Figure 4: EDS distribution of elements; SEM; EDS Slika 4: EDS-prikaz porazdelitve elementov; SEM; EDS

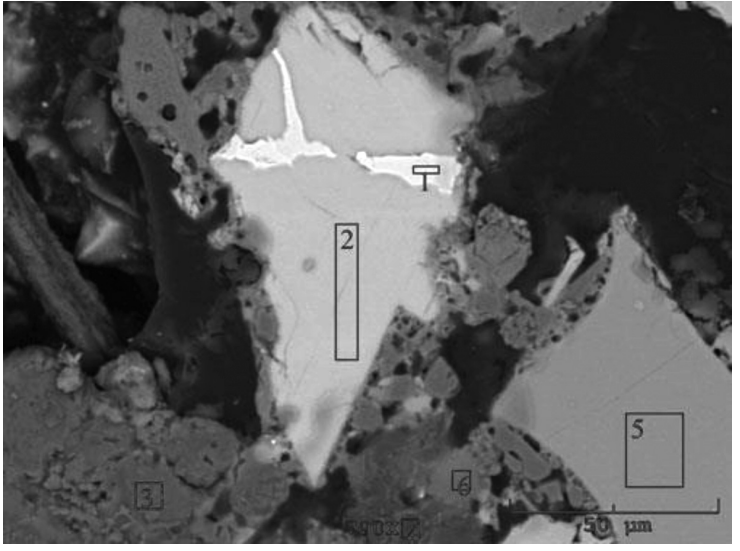

Figure 5: Microstructure of calcium silicon with a ferro-silicon inclusion

Slika 5: Mikrostruktura kalcij silicija z vključkom fero silicija

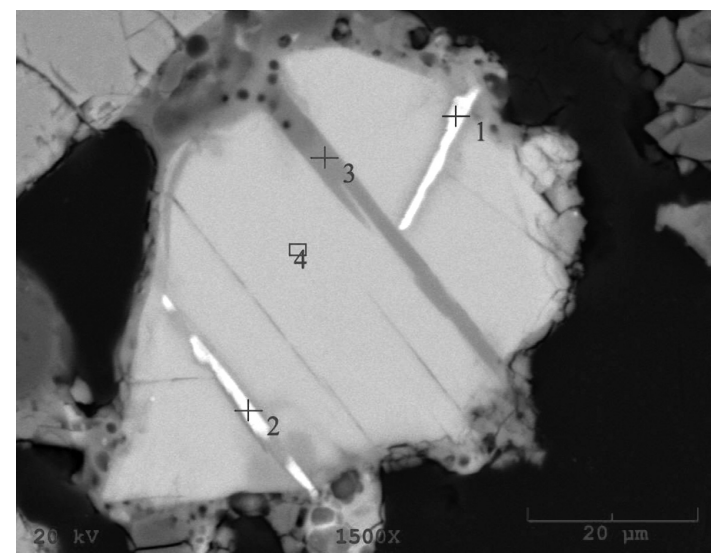

Figure 6: Microstructure of calcium silicon with included slag Slika 6: Mikrostruktura kalcij silicija z vključkom žlindre

The presence of silico manganese (SiMn) in the welding powder indicates a distribution of manganese and silicon.

Figure 5 depicts the grains of calcium silicon $(\mathrm{CaSi})$ that contain mass fractions of $46 \%$ of calcium and mass fractions of $54 \%$ of silicon and an inclusion of ferrosilicon with minimum amounts of $w(\mathrm{Si})=45 \%, w(\mathrm{Al})$ $=2.7 \%$ and about $w(\mathrm{Fe})=52 \%$. The calcium silicon grains have a slag inclusion from the production of calcium silicon (CaSi) (Figure 6).

Figure 7 presents an XRD diagram of the welding flux that shows the presence of aluminium and magnesium oxides (periclase) and calcium fluorite.

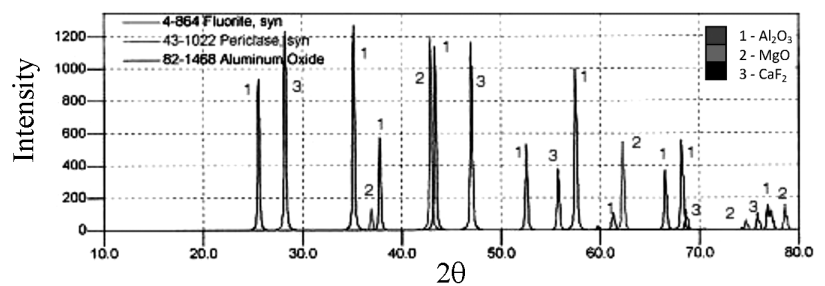

Figure 7: XRD of the welding flux FB 12.2

Slika 7: XRD-diagram varilnega praška FB 12.2 


\section{RESULTS AND DISCUSSION}

\subsection{Influence of the welding current on the welding- flux usage}

During the process of welding, the welding flux melts and a liquid slag is formed. The arc is hidden in the liquid slag, which means that the welding procedure is welder friendly. The welding current influences the time of welding and the consumption of the welding flux. Different currents were applied during the welding procedures; the surfacing weld was welded at currents of $450 \mathrm{~A}$ and $628 \mathrm{~A}$, while the weld was welded at currents of $470 \mathrm{~A}$ and $610 \mathrm{~A}$. Figure 8 represents the used flux in correlation with the welding current. Increasing the current power for the surfacing welds leads to a larger welding-flux consumption, while the time of the welding is decreased to a small degree.

\subsection{Slag of the weld at the current of $470 \mathrm{~A}$}

The welding of specimen 1 was carried out at the current of $470 \mathrm{~A}$. The slag was formed on the weld toe in the shape of a circular arch in the center, 2-3 cm wide and $3-5 \mathrm{~mm}$ thick. The weld/slag border is smooth, but some unmelted grains of the welding flux remained on its top.

Figure 9 shows the slag microstructure on the weld of steel OCR12 VM after the application of agglomerated welding flux FB 12.2. During the welding process, a liquid slag was formed, which solidified during the cooling. Aluminium and manganese oxides included in the welding flux reacted and formed a solid-solution spinel structure. The welding flux contained manganese oxide and, after the melting, it reacted with magnesium oxide which was also included in the flux.

During the welding, chromium from the base material and the welding wire is oxidized. Chromium oxide together with aluminium, magnesium and manganese oxides forms a spinel structure with a solid-solution composition $(\mathrm{MgO}, \mathrm{MnO}) \cdot\left(\mathrm{Al}_{2} \mathrm{O}_{3}, \mathrm{Cr}_{2} \mathrm{O}_{3}\right)$. After the welding, spinel contains mass fractions of $2.8 \% \mathrm{MnO}$ and mass fractions of $3.3 \% \mathrm{Cr}_{2} \mathrm{O}_{3}$.

On the left side of Figure 9, there is magnesium oxide, encircled with spinel. Solid magnesium oxide

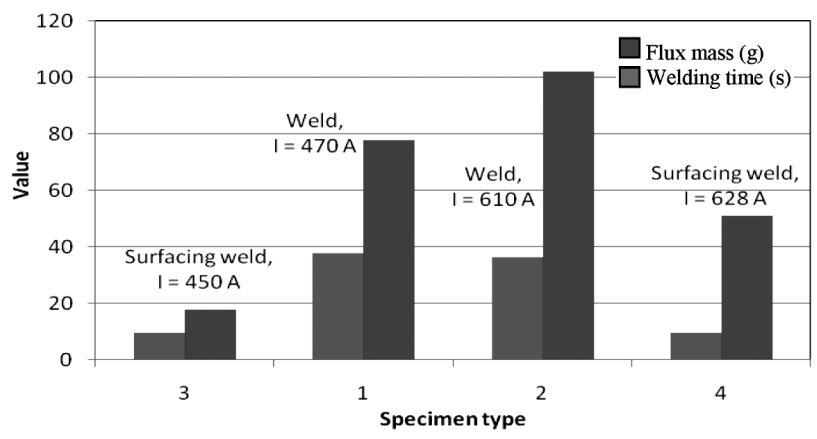

Figure 8: Welding current and flux consumption Slika 8: Varilni tok in poraba varilnega praška

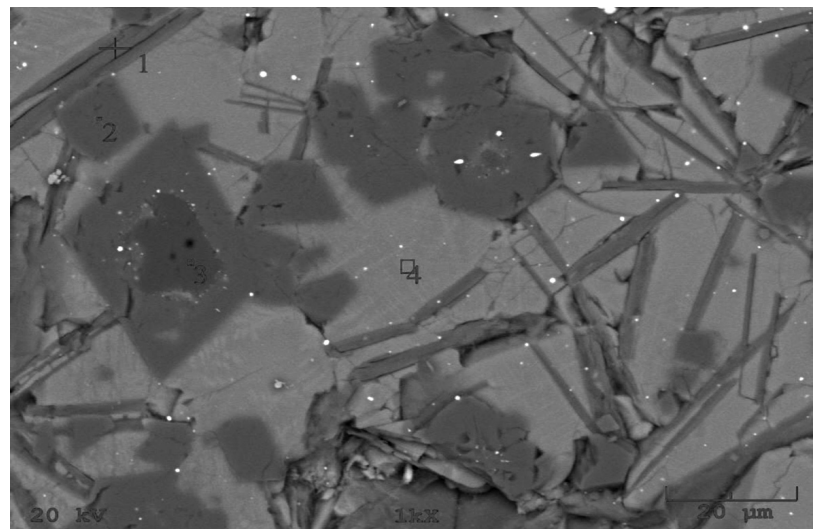

Figure 9: Microstructure of the welding slag of specimen 1 Slika 9: Mikrostruktura varilne žlindre preizkušanca 1

reacts with the liquid slag and thus spinel $(\mathrm{MgO}, \mathrm{MnO})$. $\left(\mathrm{Al}_{2} \mathrm{O}_{3}, \mathrm{Cr}_{2} \mathrm{O}_{3}\right)$ is formed on its surface. The resulting spinel prohibits a dessolution of magnesium oxide in the liquid slag.

The solidified welding slag has the following composition: magnesium oxide, spinel, a lamelar phase $\left(w(\mathrm{MgO})=21.1 \%, w\left(\mathrm{Al}_{2} \mathrm{O}_{3}\right)=18.8 \%, w\left(\mathrm{SiO}_{2}\right)=39.8\right.$ $\%$ and $\left.w\left(\mathrm{~K}_{2} \mathrm{O}\right)=10.2 \%\right)$ and the matrix $(w(\mathrm{CaO})=46.2$ $\%, w(\mathrm{MgO})=11.8 \%, w\left(\mathrm{SiO}_{2}\right)=28.9 \%, w\left(\mathrm{Al}_{2} \mathrm{O}_{3}\right)=2.8$ $\%, w(\mathrm{MnO})=4.2 \%$ and $w(\mathrm{~F})=4.5 \%)$.

Figure 10 shows an XRD diagram of the slag formed at the welding current of $470 \mathrm{~A}$. The diagram shows the peaks for aluminium oxide, spinel and calcium fluorite. In the sample, the undissolved flux from the surface of the circular arch of the slag is also observed.

\subsection{Slag of the weld at the current of $610 \mathrm{~A}$}

Figure 11 shows a SEM image of the slag formed during the welding at the current of 610 A. During the welding with a higher current, the unreacted leftovers of magnesium oxide in the welding slag are surrounded with spinel. The spinel generated during the welding with the current of 610 A contains mass fractions of 3.9 $\% \mathrm{MnO}$, mass fractions of $24.3 \% \mathrm{MgO}$, mass fractions of $5.2 \% \mathrm{Cr}_{2} \mathrm{O}_{3}$ and mass fractions of $66.6 \% \mathrm{Al}_{2} \mathrm{O}_{3}$. In the slag, tiny drops of metal (white particles) are located at the border between the spinel and magnesium oxide and in the lamelar phase.

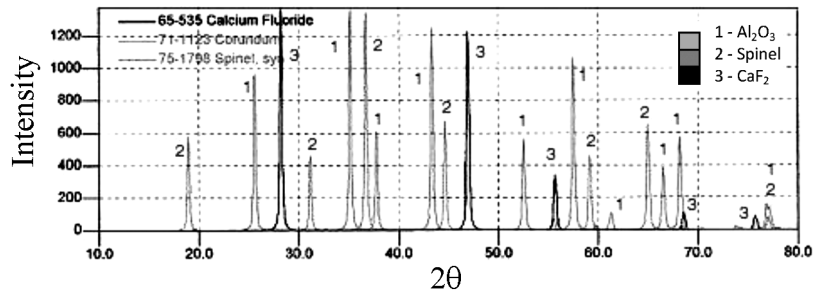

Figure 10: XRD diagram of the slag formed at the welding current of $470 \mathrm{~A}$

Slika 10: Rentgenogram žlindre, nastale pri varjenju s tokom 470 A 


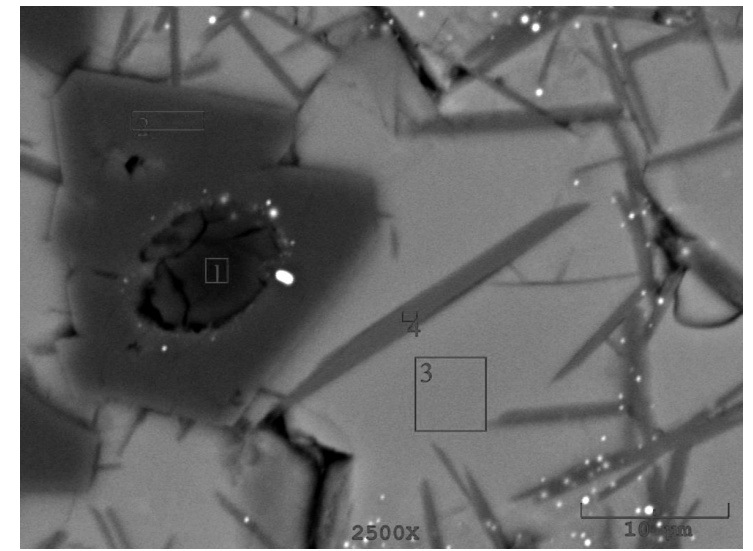

Figure 11: SEM image of welding slag; place of analysis 1 Slika 11: SEM-posnetek varilne žlindre; mesto analize 1

Figure 12 shows a SEM image of the slag, having a metalic particle with a size of $50 \mu \mathrm{m}$ and a composition of mass fractions of $27.6 \% \mathrm{Si}$, mass fractions of $4.8 \%$ Ti, mass fractions of $4.6 \% \mathrm{Cr}$, mass fractions of $33.8 \%$ Mn (label 4), while the rest is iron. The particle was formed during the metling of silico manganese and the welding wire. Its composition is not similar to the compositions of the filler or the base material. In the slag matrix, a lamellar phase and small spinel crystals containing manganese and chromium oxides are embedded.

Welding with a higher current increases the amount of $\mathrm{MnO}$ by mass fractions of $1.1 \%$ and $\mathrm{Cr}_{2} \mathrm{O}_{3}$ by mass fractions of $1.9 \%$ in the spinel, compared to the welding with the current of $470 \mathrm{~A}$.

Figure 13 presents an XRD diagram of the slag formed at the welding with current of $610 \mathrm{~A}$. The diagram shows that the slag is composed of aluminium oxide, spinel, calcium fluorite and periclase $(\mathrm{MgO})$.

\subsection{Slag of the surfacing weld at the current of $628 \mathrm{~A}$}

The specimens listed under numbers 3 and 4 are the slags of the surfacing welds. Figure 14 presents the slag formed during the surfacing with the current of $628 \mathrm{~A}$. In

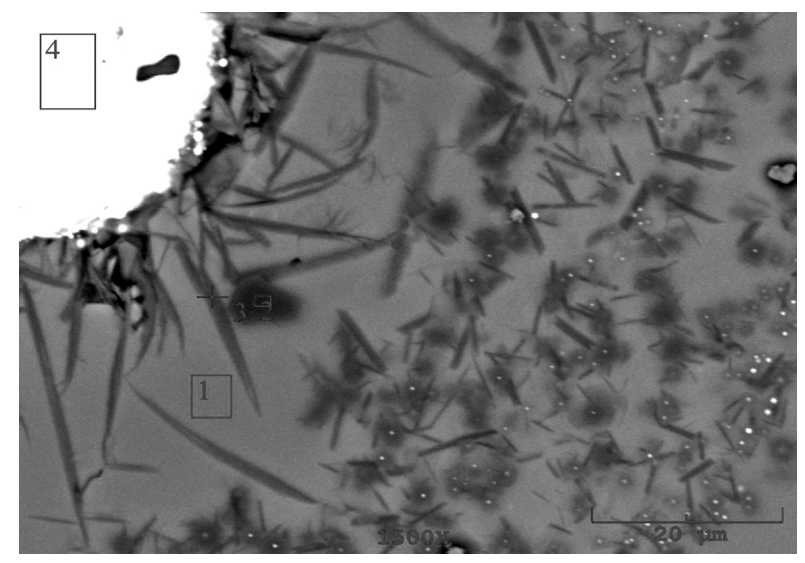

Figure 12: SEM image of welding slag; place of analysis 2 Slika 12: SEM-posnetek varilne žlindre; mesto analize 2

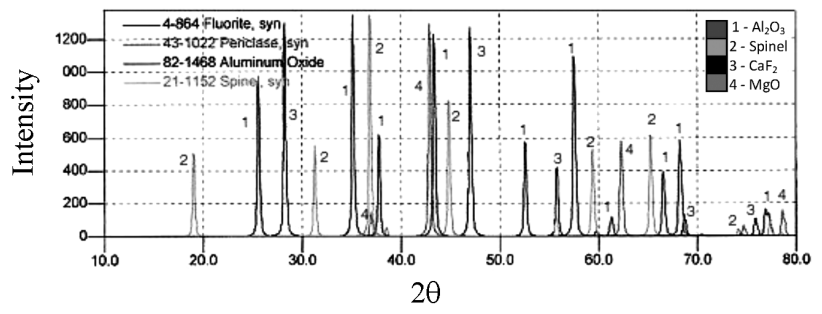

Figure 13: XRD diagram of slag formed during the welding at the current of $610 \mathrm{~A}$

Slika 13: Rentgenogram žlindre, nastale pri varjenju s tokom $610 \mathrm{~A}$

the base (matrix) of the slag, there are spinel, a lamelar phase and the leftovers of a free magnesium oxide. Compared to the surfacing with $450 \mathrm{~A}$, during the surfacing with $628 \mathrm{~A}$, the slag has more aluminium oxide and less calcium oxide. The matrix of the slag (label 2) is composed of mass fractions of $32.7 \% \mathrm{CaO}, 12.3 \% \mathrm{MgO}$, $25.6 \% \mathrm{SiO}_{2}, 16.5 \% \mathrm{Al}_{2} \mathrm{O}_{3}, 5.7 \% \mathrm{MnO}, 2.7 \% \mathrm{~F}$ and 3.2 $\%$ of $\mathrm{K}_{2} \mathrm{O}$. In the slag, there are drops of metal and most of them are located close to the lamelar phase.

\subsection{Composition of the spinel and matrix of the slag}

Figure 15 gives a graphical presentation of the contents of the oxides in the slag base (the matrix), in which the phases with higher melting points are precipitated. From the diagram it is evident that specimens 1 (470 A) and $3(450 \mathrm{~A})$ were welded with lower currents and have the same contents of silicon oxide and different contents of calcium oxide and alumina. Specimens 2 and 4, welded with higer currents (610 A, 628 A), also have different contents of calcium oxide. The content of calcium oxide in a slag decreases with the increasing current, while the content of aluminium oxide increases (Figure 15). At lower welding currents, the slag includes phases with lower melting points, while at higher welding currents more liquid slag is formed due to the melting of the oxides with higher melting points such as aluminium and magnesium oxides as well as manganese and chromium oxides.

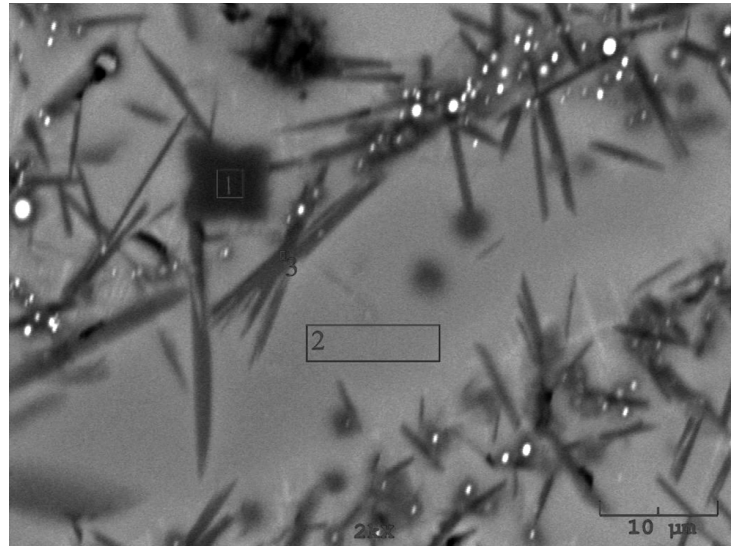

Figure 14: Micrograph of the phases in slag of specimen 4 Slika 14: Mikroposnetek faz v žlindri preizkušanca 4 


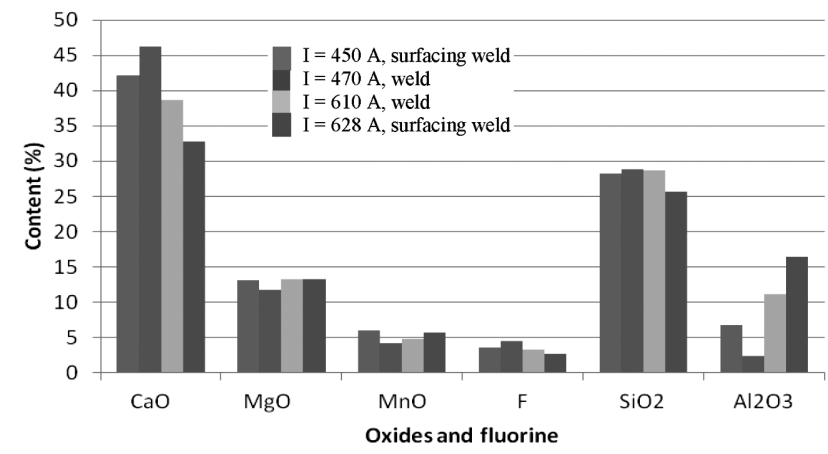

Figure 15: Relative contents of oxides and fluorine in the bases (matrices) of welding slags

Slika 15: Relativna vsebnost oksidov in fluora v osnovi (matici) varilnih žlinder

Table 4: Basicity of the base (matrix) of a slag

Tabela 4: Bazičnost osnove (matice) žlindre

\begin{tabular}{|c|c|c|}
\hline Welding flux & Current (A) & $\begin{array}{c}\text { Matrix } \\
\text { basicity }\end{array}$ \\
\hline Specimen 1 - weld & 470 & 2.14 \\
\hline Specimen 2 - weld & 610 & 1.68 \\
\hline Specimen 3 - surfacing weld & 450 & 1.94 \\
\hline Specimen 4 - surfacing weld & 628 & 1.50 \\
\hline
\end{tabular}

The content of the formed spinel depends on the welding current. With an increase in the welding current the content of manganese oxide increases from 2.8 to 3.9 $\%$ of mass fractions and chromium oxide also increases from 3.3 to $7.3 \%$ of mass fractions. Figure 16 presents the change in the composition of the spinel in relation to the welding current.

We calculated the basicity ${ }^{15}$ of the main components in the slag with Equation (1):

$B=\frac{\mathrm{CaO}+\mathrm{MgO}+\mathrm{BaO}+\mathrm{CaF}_{2}+\mathrm{Na}_{2} \mathrm{O}+\mathrm{K}_{2} \mathrm{O}+0.5 \cdot(\mathrm{MnO}+\mathrm{FeO})}{\mathrm{SiO}_{2}+0.5 \cdot\left(\mathrm{Al}_{2} \mathrm{O}_{3}+\mathrm{TiO}_{2}+\mathrm{ZrO}_{2}\right)}$

The content of the base (matrix) of a slag and its basicity also vary with respect to the welding current. The basicity is calculated with Equation (1) and it

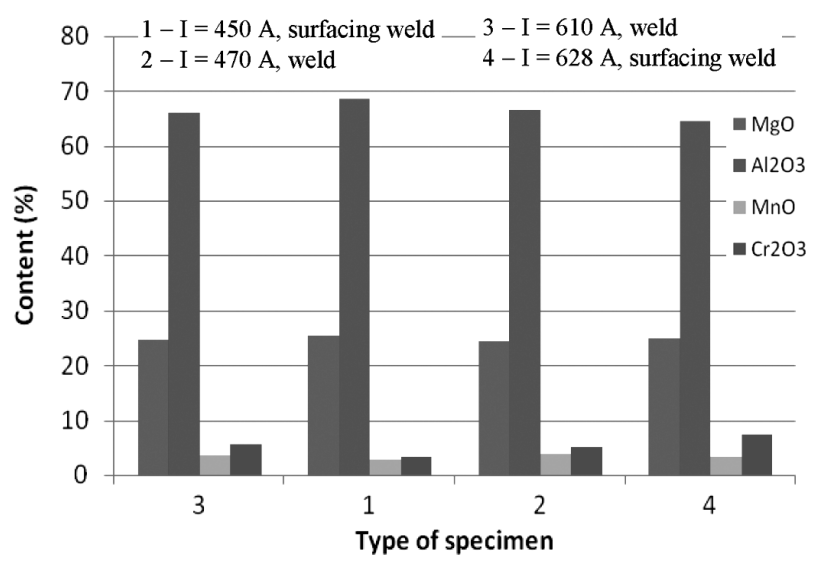

Figure 16: Composition of the spinel in relation to the welding current

Slika 16: Sestava spinela v odvisnosti od toka pri varjenju

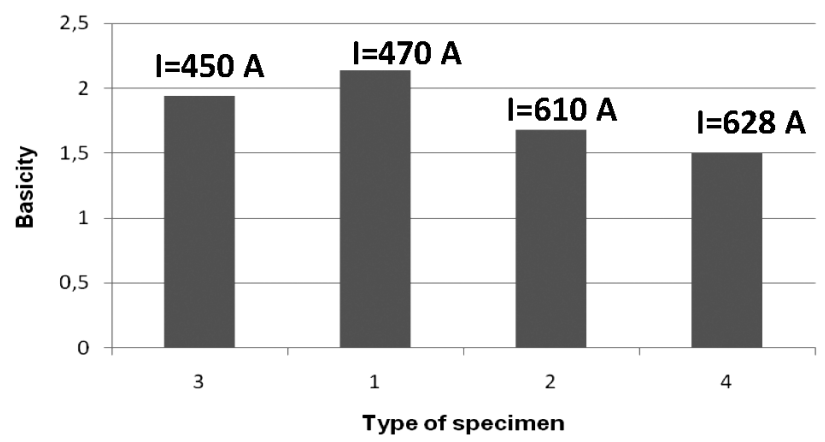

Figure 17: Basicity of the base (matrix) of the welding slag Slika 17: Bazičnost osnove (matice) varilne žlindre

changes with the welding current, as presented in Table 4.

Lower welding currents also diminish the loss of the alloying elements. The calculated values of the basicity show that the basicity of the matrix of a slag is higher at lower welding currents (Figure 17) because of the content of $\mathrm{Al}_{2} \mathrm{O}_{3}$ in the slag melt.

\section{CONCLUSIONS}

During the submerged-arc welding of steel OCR 12 VM, slag solidifies above the weld in the form of a circular arch. The contact area with the slag has a smooth glassy shine. On the contrary, at the contact with the slag surface, the leftovers of undissolved welding flux are observed.

The agglomerated welding flux is in the form of pellets with a size of $0.2-1.8 \mathrm{~mm}$. During the welding, the slag is liquid. The solidified weld slag contains aluminum and magnesium oxides, spinel, a lamellar phase and the matrix. The composition of the matrix is similar to that of mineral cuspidin ${ }^{16}\left(3 \mathrm{CaO} \cdot 2 \mathrm{SiO}_{2} \cdot \mathrm{CaF}_{2}\right)$ but it also contains aluminium, potassium and magnesium oxides. The magnesium oxide in the welding slag is surrounded by spinel.

Spinel ${ }^{16}$ with a complex composition $(\mathrm{MgO}, \mathrm{MnO})$. $\left(\mathrm{Al}_{2} \mathrm{O}_{3}, \mathrm{Cr}_{2} \mathrm{O}_{3}\right)$ is formed from magnesium and aluminium oxides, with smaller amounts of manganese and chromium oxides.

The composition of the welding-slag matrix depends on the welding current. At higher welding currents more aluminium oxide is formed.

The welding slag generated during the submerged welding can be a valuable raw material for the production of a new welding flux.

\section{REFERENCES}

${ }^{1}$ H. Grajon, Bases métallurgiques du soudage, Publications de la Soudure Autogène, 41, Institute de Soudure, Paris, 1989

${ }^{2}$ K. Singh, V. Sahni, S. Pandey, Slag Recycling in Submerged Arc Welding and its Influence on Chemistry of Weld Metal, Asian Journal of Chemistry, 21 (2009) 10, 047-051 


\section{PRIJANOVIČ TONKOVIČ, J. LAMUT: PHASE ANALYSIS OF THE SLAG AFTER SUBMERGED-ARC WELDING}

${ }^{3}$ Submarged arc welding, Copyright 1982, Muller Electric Mfg. Co., (Rev. 11/85), (http://www.millerwelds.com/pdf/spec_sheets/Sub merged.pdf)

${ }^{4}$ S. Durić, B. Sabo, M. Perović, P. Dašić, Matematični model odvisnosti oblike in dimenzij zvara od parametrov navarajanja pri postopku EPP - II. del, Varilna tehnika, 59 (2010) 3, 20-40

${ }^{5}$ R. Kejžar, Platiranje konstrukcijskih jekel z navarjanjem, Kovine zlitine tehnologije, 28 (1994) 2, 95-100

${ }^{6}$ R. Kejžar, B. Kejžar, Dodajni materiali na osnovi izbranih sintetičnih repromaterialov z dodatkom alkalijskih oksidov, Kovine zlitine tehnologije, 28 (1994) 3

${ }^{7}$ A. M. Paniagua-Mecado, V. M. Lopez-Hirata, Chemical and physical propertis of flux for SAW low-carbon steels, Instituto Politechnico National Mexico, 2011 (www.intechnopen.com)

${ }^{8}$ J. Singh, K. Singh, J. Garg, Reuse of Slag as Flux in Submerged Arc Welding \& its Effect on Chemical Composition, Bead Geometry \& Microstructure of the Weld Metal, International Journal of Surface Engineering \& Materials Technology, 1 (2011) 1, 24-27

${ }^{9}$ T. Lau, G. S. Weatherly, A. McLean, Gas/Metal/Slag Reactions in Submerged Arc Welding Using $\mathrm{CaO}-\mathrm{Al}_{2} \mathrm{O}_{3}$ Based Fluxes, Welding Journal, 65 (1986) 2, 343-347
${ }^{10}$ D. Mahto, A. Kimar, Novel Methos of Productivity Improvement and Waste Reduction Through Recycling of Submerged Arc Welding Slag, Jordan Journal of Mechanical and Industrial Engineering, 4 (2010) 4, 451-466

${ }^{11} \mathrm{http}: / /$ www.elektrode.si/html/slo/katalog/index_katalog.html

${ }^{12}$ B. Kosec, G. Kosec, M. Soković, Case of temperature field and failure analysis of die-casting die, Journal of Achievements in Materials and Manufacturing Engineering, 20 (2007) 1/2, 471-474

${ }^{13}$ F. Legat, Orodna jekla v praksi, samozal. F. Legat, Medium, Žirovnica 2013

${ }^{14}$ M. P. Tonkovič, A. Nagode, L. Kosec, Mehanizem nastanka sekundarnega ledeburita med varjenjem orodnega jekla, IRT 3000, 5 (2012), 17-21

${ }^{15}$ I. Polajnar, Varjenje pod praškom I. del: Varilni procesi in oprema, Inštitut za varilstvo, Specializacija IWE/IWT, Ljubljana 2013/2014

${ }^{16}$ F. Trojer, Die oxydische Kristallphasen der anorganischen Industrieprodukte, E. Schweizerbartsche Verlagsbuchhandlung, Stuttgart 1963 